Please note this the authors' pre-publication draft copy of the article published in the International Journal of Tourism Research (2014). The original publication is available at DOI: $10.1002 /$ jtr.1993

\title{
Conceptualising Customer-to-customer Value Co-creation in Tourism
}

\author{
Ivana Rihova ${ }^{1}$, Dimitrios Buhalis ${ }^{2}$, Miguel Moital $^{3}$ and Mary-Beth Gouthro ${ }^{3}$ \\ ${ }^{1}$ School of Marketing, Tourism and Languages, The Business School, Edinburgh Napier University, Edinburgh, UK \\ ${ }^{2}$ International Centre for Tourism and Hospitality Research, Bournemouth University, Poole, UK \\ ${ }^{3}$ School of Tourism, Bournemouth University, Poole, UK \\ Correspondence to: \\ Dr Ivana Rihova, School of Marketing, Tourism and Languages, The Business Schoo, Edinburgh Napier University, Craiglockhart \\ Campus, Edinburgh, EH14 1DJ, UK \\ Email: i.rihova@napier.ac.uk
}

\begin{abstract}
The notion that tourists actively co-create value with organisations is increasingly acknowledged in tourism marketing. Yet, not much is known about the processes in play when customers co-create value with each other. This conceptual paper offers a theoretical basis for the study of customer-to-customer co-creation in tourism contexts, while debating the epistemological assumptions of value-related research in tourism. Proposed conceptual framework posits that value is socially constructed and embedded in tourists' social practices.
\end{abstract}

Keywords: Tourism experience; co-creation; value; customer-to-customer; social practices

\section{When citing this publication, please use the following reference:}

Rihova, I., Buhalis, D., Moital, M., Gouthro, M-B. (2014) Conceptualising customer-tocustomer co-creation in socially dense tourism contexts. International Journal of Tourism Research. DOI: 10.1002/jtr.1993 


\section{Conceptualising Customer-to-customer Value Co-creation in Tourism}

\section{Introduction}

Tourism consumption often takes place in social contexts, in which interactions and shared experiences with other tourists form a crucial part of the service experience., Tourists participating in guided tours, cruise holidays or events and festivals come together to spend time with significant others and to meet other tourists (Brown et al., 2002; Huang and Hsu, 2010; Packer and Ballantyne, 2011; Prebensen and Foss, 2011). In the course of their social experiences tourists bond, cement social relationships and enhance their social skills (e.g., Arnould and Price, 1993; Wilks, 2011), thus co-creating 'value'. Nonetheless, not much is known about what this value is and how it is cocreated. A growing number of tourism marketing studies explore the concept of value co-creation (e.g., Binkhorst and Den Dekker, 2009; Cabiddu et al., 2013; Griessmann and Stokburger-Sauer, 2012; Sfandla and Björk, 2013). These studies are, however, largely limited to co-creation of value between the tourism organisation and the tourist. More in-depth insights are needed that would acknowledge the ability of tourists to cocreate value with each other, as opposed to with the organisation.

Looking more closely at the notion of value, tourism marketing literature is dominated by the outcome oriented 'features-and-benefits' value perspective. This approach focuses on how the tourism provider can design and deliver value or valuable experience through service attributes, so that it is perceived by tourists as benefits. This does not, however, sufficiently acknowledge the active role of tourists as value cocreators. Recently, a move toward the 'value-in-' perspective is evidenced in tourism marketing research, building on the concept of the Service-Dominant logic (S-D logic) in marketing (Vargo and Lusch, 2004; 2008). A number of scholars present S-D logic as a new paradigm that offers interesting opportunities for tourism marketing research, and the study of value co-creation in particular (Li and Petrick, 2008; Sfandla and Björk, 2013; Shaw et al., 2011).

This conceptual paper aims to contribute theoretically in tourism marketing research and specifically to the study of value and co-creation in three ways. Firstly, the paper argues that the principles of S-D logic do not go far enough in acknowledging the complexities inherent in the social, $\mathrm{C} 2 \mathrm{C}$ interaction-rich context of tourism 
consumption. The recently emerged Customer-Dominant [C-D] logic (Heinonen et al., 2010) in marketing is put forward as an alternative orientation. Secondly, this paper engages in a debate of the paradigmatic and epistemological foundations of the experience- vs. practice-based value co-creation perspectives in C-D logic. It does so to build a robust theoretical basis for $\mathrm{C} 2 \mathrm{C}$ co-creation research in tourism.

Finally, a conceptual framework is posited that conceptualises $\mathrm{C} 2 \mathrm{C}$ co-creation in tourism. This is done by presenting value as a complex, multi-layered construct that takes into account the social structures inherent in many tourism consumption contexts, as well as the attributes of practicing subjects (i.e. the various social units involved in C2C value co-creation). The framework offers a novel methodological and epistemological basis for future $\mathrm{C} 2 \mathrm{C}$ co-creation studies in a variety of social experience tourism contexts. As such, it represents a theoretical contribution within value and co-creation research in tourism marketing.

\section{Value perspectives in tourism research}

The notion of 'value' is central in the context of this conceptual paper. However, within marketing and consumer research the term is rather ambiguous (Woodall, 2003). Before proceeding to discuss $\mathrm{C} 2 \mathrm{C}$ co-creation in tourism, two perspectives on value are critically reviewed that appear in consumer and marketing research, and tourism marketing literature specifically: The 'features-and-benefits' approach, as an outcomeoriented value ontology grounded within a positivist paradigm (Tronvoll et al., 2011); and, the 'value-in-' perspective that primarily draws on the principles of the S-D logic and corresponds with a more reflexive, interpretive paradigm that can increasingly be found in tourism experience research (Ryan, 2002; Uriely, 2005).

\section{Delivering value for customers: the 'features-and-benefits' approach}

In consumer research 'value' is mostly viewed as customers' personal evaluation of the trade-offs between the benefits they receive and the sacrifices they make (Zeithaml et al., 1988). More recently, 'customer-perceived value' (Kotler et al., 2009) or 'value for 
the customer' (Woodall, 2003) is conceptualised as judgment perception of the potential economic, functional and psychological benefits customers attribute to, or expect to receive from, the marketer's offering (Kotler et al., 2009; Woodall, 2003). Approaching value from a rationalist, cognitivist perspective, researchers are concerned with how customers (sub)consciously evaluate, assess, reason about, judge, and balance against the value of something, allowing for calculated predictions to be made as to customers' purchase and consumption choices. In contrast to the cognitivist approach, the 'experience economy' (Pine and Gilmore, 1999) moves toward the more symbolic, emotional aspects of consumption. The focus is on experiences as a vehicle for delivering positive customer value.

Both the cognitivist and the experience economy approach are predominantly oriented at value as service attributes or experiential features that realise some positive outcomes or benefits for customers. For instance, researchers aim to pinpoint specific types of value (value outcomes) that tourists expect to derive from their experiences (e.g., Turnbull, 2009). In a similar way, tourists' needs and motivations are studied as an indicator of value sought (e.g., Pegg and Patterson, 2010), with findings used to aid tourism marketers' decisions regarding effective design and delivery of 'memorable' service experiences (Oh et al., 2007; Walls, 2013). Alternatively, tourists' 'quality experiences' are scrutinised as an important mediator between service performance factors, tourists' overall service/ experience satisfaction, and their future behaviour intentions (Cole and Chancellor, 2009). Outcome-oriented measures, such as the expectancy disconfirmation approach, are adopted in service evaluation studies, with authors measuring tourists' perceptions of service quality as indicators of value (Baker and Crompton, 2000; Thrane, 2002).

Ontologically, the features-and-benefits value perspective distinguishes clearly between the subject (the tourist) and the object of consumption (the tourism service experience), with researchers focusing predominantly on how the subject perceives and evaluates the object (i.e. service or some experience attributes). While such approach can lead directly to operationalisable solutions for tourism organisations, it assumes that the organisation acts as a 'producer' or 'enabler' of tourists' value outcomes. It promotes value creation for the tourist, who somewhat passively and uncritically accepts the organisation's offering at its 'face value'. Yet, as some authors (Goulding 
and Shankar, 2011; Kim and Jamal, 2007) point out, tourists often look for more authentic ways in which to construct and manifest their experiences. For Selby (2004, p. 191), tourists are "dynamic social actors, interpreting and embodying experiences, whilst also creating meaning and new realities through their actions". Aiming to objectively determine and design value or valuable experiences so that through various attributes they realise benefits to tourists could represent a somewhat prescriptive, reductionist paradigm for value research. Tourism marketers benefit from more holistic value perspectives that recognise the active role of tourists as co-creators of value and experiences.

\section{Co-creating value with customers: the 'value-in-' perspective}

The above critique of the features-and-benefits perspective builds on conceptualisation of value and re-definition of the relationship between the provider and customers as proposed within the S-D logic in marketing. Introduced by Vargo and Lusch in 2004, the S-D logic focuses on customers' active role in co-creating value and valuable experiences with the service organisation. Vargo and Lusch (2004) argue that by viewing value as attributes that are embedded in a service and can be 'exchanged' to realise benefits for the customer marketers subscribe to a static, outcome-oriented 'goods-dominant' logic. Instead, in the increasingly dynamic, process-oriented context of service experiences, marketer's role is limited to offering 'value propositions' to customers (Vargo and Lusch, 2004). Co-creation is then viewed as a joint valuerealising process that occurs as the organisation and its customers interact (Payne et al., 2008). 'Value-in-use' (Vargo and Lusch, 2004) or '-in-context' (Vargo and Lusch, 2008) is considered as a dynamic, situational, meaning-laden, and phenomenological construct that emerges when customers use, experience, or customise marketers' value propositions in their own experience contexts.

According to Vargo and Lusch (2004), all social and economic actors are resource integrators. Customers are therefore capable of co-creating value by integrating their various 'operand' (tangible resources that can be allocated or acted upon; e.g. the physical aspects of a tourism destination) and 'operant' resources (those that act on other resources and over which the actors has 'authoritative' capability; e.g. skills and 
knowledge) (Vargo, 2011). Customers' resource integration is typically studied in the business-to-customer (B2C) context (Prebensen et al., 2013) but the resourceintegration approach to the study of $\mathrm{C} 2 \mathrm{C}$ co-creation processes is also evident in a small number of tourism marketing studies. For instance, Baron and Harris (2010) adopt the resource-based view to study co-creation of positive experiences (i.e. value) in the social context of gap-year travel. Other studies (Finsterwalder and Tuzovic, 2010) note that in the context of group consumption in services, co-operation, participation in, and identification with group goals as operant resources play an important role in cocreating positive outcomes for individual group members, but also in co-creating shared value for the group. Tourists' co-creation in virtual contexts is also explored using the resource-integrating approach (Binkhorst and Den Dekker, 2009; van Limburg, 2009).

From the tourism organisation's perspective, those tourists who adopt participatory and active co-creation roles are viewed as particularly useful. While contributing to a better service experience for other tourists, these individuals are more likely to be satisfied with their own experiences, and consequently become loyal to the organisation (Bendapudi and Leone, 2003). Interacting and resource integrating tourists can therefore become a source of innovation for the service organisation through their own value co-creation (van Limburg, 2009). Tourists-producers who co-create value for other tourists become essentially an operant resource from which the organisation can learn and develop their offering. The boundaries of the tourist's 'consuming' role become blurred in reaching toward a more work-like 'productive' role, adding value to the organisation's offering (Cova and Dalli, 2009).

The strong focus of the resource-based approach in S-D logic on tourists' worklike resource-integrating activities is criticised by some authors (Korkman, 2006) as too mechanistic. McColl-Kennedy and Tombs (2011) rightly ask whether value is or is not always co-created in the course of customers' resource integration, and for whom it is in fact co-created. Co-creation may not necessarily result in the emergence of servicerelated value where customers are not interested or directly involved in the company's value offering (Grönroos, 2008). Tourists' experiences at festivals, for instance, arise from 'extraordinary', non-routine social occasions set apart from every-day life (Getz, 2007). They involve a range of rituals, participation in which can lead to the emergence of shared temporary social structures and communities (Kim and Jamal, 2007; Turner, 
1982). These temporary communities may surpass the service situation and develop into 'festival careers' (Getz, 2007; Mackellar, 2009) that involve ongoing C2C co-creation of value outside the immediate service situation. Value co-creation in such circumstances takes place in customers' own social contexts (Grönroos, 2011; Heinonen et al., 2010). Services as marketer-provided resources provide merely one of the outlets for $\mathrm{C} 2 \mathrm{C}$ value co-creation (i.e. the co-creation of value among customers) that takes place both before and after service-related experience and goes beyond service-related value.

A small number of researchers based around the Nordic School of Services criticise the resource-based view, and S-D logic in general, as too provider-oriented (Grönroos and Voima, 2011; Heinonen et al., 2010; Voima et al., 2010). Introducing the term Customer-Dominant logic (C-D logic) to reflect a truly customer-centric focus, these authors argue that rather than treating their customers as partial workers or partners in co-creation (a business-to-customer focus in co-creation research), service organisations should strive to find out of what customers actually do with the service to accomplish their own goals. As Heinonen et al. (2010, p. 533 emphasis added) note, marketing researchers would benefit from a more "holistic understanding of customers' lives, practices and experiences, in which service is naturally and inevitably embedded"..Such contextual enquiry into customers' own social sphere could be converted into specific ways for organisations to support and facilitate customers' cocreation (Grönroos and Voima, 2011), including co-creation in C2C interaction-rich contexts such as tourism.

To further elaborate on how the C-D logic in marketing could contribute theoretically in the context of $\mathrm{C} 2 \mathrm{C}$ co-creation research, the following section looks in detail at two perspectives through which $\mathrm{C} 2 \mathrm{C}$ co-creation can be studied in tourism contexts: the experiential perspective and the practice-based approach.

\section{Illuminating $\mathrm{C} 2 \mathrm{C}$ co-creation: social experiences and practices in tourism contexts}

The C-D logic in marketing suggests that in order to remain competitive in a volatile marketplace, organisations should focus solely on the customer (Heinonen et al., 2010) and the co-creation practices and experience in his or her own social context. 
Nevertheless, there is still little clarity around the differences between the ontological and epistemological assumptions inherent in C-D logic's perspectives on co-creation (Helkkula and Kelleher, 2011). Paradigmatic foundations of value creation through social experiences and practices are therefore critically discussed in this section.

\section{Co-creating subjective value through social experiences}

Holbrook (1999, p. 9 emphasis in original) views value as something that "resides not in the product purchased, not in the brand chosen, not in the object possessed, but rather in the consumption experience( $s$ ) derived therefrom". This notion is inherent in Vargo and Lusch's (2008) highly subjective, idiosyncratic, and phenomenological value-in-use, and expanded on within C-D logic as 'value-in-the-experience' (Helkkula et al., 2012). Building on the phenomenological concept of lived experiences (Husserl, [1936] 1970), the value-in-the-experience perspective views as data customers' highly personal interpretations of value that emerge from these experiences (Helkkula and Kelleher, 2011; Helkkula et al., 2012). Unlike the notion of experiences as value outcomes (Pine and Gilmore, 1999), the phenomenological view of value assumes that only the tourist him- or herself can make sense of his or her internal, subjective experiences and value.

This approach is in line with the experiential-phenomenological orientation adopted in tourism experience studies (Arnould and Price, 1993; Ryan, 2002). In order to better reflect the subjective nature of tourism experiences and the value and meanings attached to them, authors explore them as 'extraordinary' or 'flow' experiences (Getz, 2007; Morgan, 2007). Based on the psychological study of individuals' autotelic activities such as art making, rock climbing, or dancing, Csikszentmihalyi (1997) conceptualises flow as a (positive) state of 'wholeness', complete involvement and total immersion/ absorption. Csikszentmihalyi (1997) and other authors (e.g., Walker, 2010) note that flow occurs when individuals interact with each other. (Social) flow is often

presented as the 'ideal state' through which interacting tourists realise value in the form of positive emotional outcomes (Arnould and Price, 1993).

Parallels can be drawn between (social) flow theory and the resource-based perspective on co-creation in S-D logic. Balancing tourists' personal antecedents (skills) 
and the experiential conditions (challenges) in order to achieve positive psychological outcomes for individuals is very much in line with S-D logic's focus on resource configurations. Tourists co-create value by integrating their personal skills (operant resources) with the challenges (operand resources) posed by the service setting, including the social aspects of that setting in the sense of $\mathrm{C} 2 \mathrm{C}$ interactions. Flow results in positive emotional states, while value creation is viewed, on a general level, as a process which increases the customer's well-being in some way (Vargo and Lusch, 2008). Nevertheless, adoption of a phenomenological 'value-in-the-flow' theory could lead researchers to focus too much on the inputs (resources/ skills) and outcomes (positive emotions/ positive value), resulting in somewhat simplified dichotomous representations of the value construct.

An additional limitation of the experiential approach to the study of $\mathrm{C} 2 \mathrm{C}$ cocreation in tourism contexts lies in its epistemological assumptions. Individuals' inner mental processes and subjective sense making may not be evidence of what actually 'happened' in social contexts (Löbler, 2011). Thus, purely phenomenological representations in value enquiry can only partially illuminate $\mathrm{C} 2 \mathrm{C}$ co-creation. Tourism marketers would benefit from more holistic approaches that would also allow for exploration of tourists' mundane and routine social practices, as these are also embedded with value (Helkkula and Kelleher, 2011; Holt, 1995; Holttinen, 2010; Korkman, 2006; Schatzki, 2001). For instance, festival tourists' narratives of the subjective meanings they associate with extraordinary, emotional experiences may not reflect value creation in the more mundane social practices of dinner sharing or camping at festivals (Begg, 2011). Thus, an alternative focus on the inter-subjective and socially constructed nature of value is represented in the practice-based approach in $\mathrm{C} 2 \mathrm{C}$ cocreation research, reviewed next.

\section{Social practices and co-creation of socially constructed value}

Consumption of tourism experiences is often shared and collective (Brown et al., 2002). While subjective perceptions may vary, social consensus among the majority will shape the development of how individuals communicate and understand what is valuable (Edvardsson et al., 2011). Consequently, value assessments become more than 
individual and subjective. A number of co-creation studies conducted within various interaction-rich consumption contexts therefore draw on social construction theories (Berger and Luckmann, 1967), to help shift emphasis away from customers' subjective perceptions and to focus on value that is socially constructed (Helkkula and Kelleher, 2011; Holt, 1995; Korkman, 2006; Warde, 2005).

Social constructionists (e.g., Berger and Luckmann, 1967) hold that knowledge and meaning are created, realised and reproduced by social actors in an inter-subjective manner. By extension, value can also be understood on an inter-subjective (mutual or shared) level (Edvardsson et al., 2011; Voima et al., 2010). Co-creation as a phenomenon embedded in the social world can then be studied by interpreting shared social structures (i.e. norms, rule and role structures), and their interaction and reproduction by individuals (Edvardsson et al., 2011). Conversely, it is difficult to get away completely from the individual. While the shared, collective social forces are dominant, the needs, preferences, and habits of individuals still play a part in value cocreation and determination.

To reconcile the conflict implied in this last point, tourism researchers can draw on the notion of social practices. As Schatzki (1996, p. 13) notes, "both social order and individuality [...] result from practices". Practices are not simply bodily actions or behaviours in a sociological sense. Rather, they are 'ways of doing', or contexts in which these bodily actions, tasks and behaviours that the practice requires are carried out (Schatzki, 2001). In C-D-related research social practices are viewed as a "contextladen arena for value creation" (Holttinen, 2010, p.102). The tourist as subject, the object of consumption, and the context in which value is co-created, are no longer separate entities. Instead, practices combine these elements in an assemblage of images (mental states, meanings, symbols), tools/skills (personal resources, 'know-how', previous experience), and the physical space (consumption context), performed through actors' routine-like bodily actions (Korkman, 2006; Warde, 2005). Tourists actively use their skills and know-how to negotiate various practices. At the same time, they are mere carriers of social practices, performing the various acts and tasks that the practice requires. 
Korkman (2006) argues that by identifying and understanding in depth the anatomy of customers' value-creating social practices organisations can enhance customers' value through positive interventions. This can be done by facilitating and supporting existing co-creation practices, reducing those practices that are not as attractive to carry out, or creating new practices by transferring them from other, similar contexts. Instead of 'exploiting' customers' competences (i.e. operant resources) as in the resource-integrating view, knowledge of their social practices allows organisations to 'grow' and enhance customers' co-creation capability. As such, the practice-based view on value co-creation presents a perspective that could reveal useful theoretical and practical insights for tourism marketing. The following section therefore looks more closely at social practices in tourism, and relates them to value and $\mathrm{C} 2 \mathrm{C}$ co-creation in the proposed conceptual framework.

\section{Using practices to explore $\mathrm{C2C}$ co-creation: conceptual framework}

There are some examples of the application of practice theory in consumer research, and to a lesser extent, in tourism. For instance, observing social interactions among baseball spectators, Holt (1995) identifies through observation a number of consumption practices through which the spectators co-create value, including playing through communing and socialising. In his doctoral thesis focusing on family consumption practices in a leisure cruise setting Korkman (2006) identifies a total of 21 social practices. He categorises these according to actors who carry out these practices (i.e. family/ parents/ child), emphasising ethnography and situated observation as essential for embodied understanding of practices. Rantala's (2010) account of tourist-guide practices observed during forest tours highlights the importance of the context, both physical and symbolic, in understanding how tourists' practices are enacted.

Unlike the studies outlined above, this paper does not aim to identify and empirically examine the co-creation practices of tourists in specific social contexts. Rather, the focus is on emphasising the dynamic, multi-dimensional and contextual nature of $\mathrm{C} 2 \mathrm{C}$ co-creation. To this end, it is important to understand the nature of the tourism context; not simply its physical or service aspects, but rather, its socially constructed elements. To this end, the liminoid nature of tourism contexts needs to be 
highlighted. Drawing on Turner's (1982) work, Cohen (1988) and other authors (MacCannell, 1976; Ryan, 2002) conceptualise tourism experiences as a liminoid phenomenon. Tourists separate themselves from their everyday lives into "socially sanctioned periods of play and relaxation" (Ryan, 2002, p. 4). Upon return, tourists are re-integrated back into their ordinary environments, the reversion often accompanied by a sense of change, transformation, or even feelings of loss (Getz, 2007). This three-stage ritual process (Turner, 1982) is reflected in the conceptual framework (Figure 1).

The top part of the framework focuses on the notion of tourists' $\mathrm{C} 2 \mathrm{C}$ co-creation that takes place on multiple social levels: 'Detached Tourist'; 'Social Bubble' and 'Communitas' (Rihova et al., 2013). As noted in practice-based co-creation research, specific service contexts may represent only an outlet for tourists' value co-creation (Grönroos, 2011; Heinonen et al., 2010). This on-going nature of C2C co-creation practices is illustrated in the framework by the means of the three levels encompassing the pre-, during- and post-liminoid stages of the tourism experience. Additionally, a feedback loop links the post- and pre-liminoid stages of the tourism experience. Tourists' $\mathrm{C} 2 \mathrm{C}$ co-creation may result in favourable value that facilitates tourists' reengagement in certain practices, and from the tourism marketers' perspective can potentially lead to re-visit intentions.

* Please insert Figure 1 about here

Tourists' value-in-social-practice (Holttinen, 2010) is therefore viewed as an intersubjective, dynamic, and multi-level construct. Unlike the more traditional features-andbenefits value approach or the phenomenologically determined experiential value-inperspective, the notion of value-in-social-practice highlights the importance of understanding and facilitating tourists' $\mathrm{C} 2 \mathrm{C}$ co-creation practices, rather than aiming to determine tourists' benefits or subjective value perceptions.

To provide specific examples of some of the practices of relevance on the 'Detached Tourist' level, tourists on a beach holiday or at campsites may for instance build physical barriers in order to 'Detach' themselves from others. Couples at opera festivals may not be interested in interacting with strangers, but rather, attend for the 
sole purpose of experiencing the music (Wilks, 2011). In other cases, tourists visit festivals or go on holiday as part of a group of previously acquainted companions. The 'Social Bubble' level co-creation may then involve practices such as friends planning their trip together and sharing memories long after the trip (e.g. Clarke, 2013; Lehto et al., 2009), or families eating, shopping and playing together (Korkman, 2006). Lastly, C2C co-creation practices may be performed on the 'Communitas' level; emerging particularly within the confounds of the liminoid space where a degree of homogeneity, sense of togetherness, and belonging develops among tourists who share their experiences (Turner, 1982). 'Rites of integration' are performed (Arnould and Price, 1993), e.g. at festivals tourists engage in ludic practices of playing together, wearing of costumes or escapism in overconsumption of alcohol.

Importantly, the degree to which social practices are performed at these levels is influenced both by personal and contextual factors, as seen in the top part of Figure 1. Tourists' personal resources - the stock of skills, tools, knowledge or know-how (Korkman, 2006), can determine whether a more or less participatory role in co-creation practices is adopted; i.e. whether tourists detach themselves, co-create with family and friends, or interact with strangers on the Communitas level. For instance, Levy and Getz's (2012) research indicates that personality, perceived similarity and mood have impact on the degree to which outdoor tour participants engage with strangers.

Additionally, as argued in the previous section, $\mathrm{C} 2 \mathrm{C}$ co-creation in social practices is guided by the ways in which tourists interpret and negotiate the socially constructed shared images and social (rule and norm) structures pertaining to specific consumption contexts in which practices are performed. This is of importance particularly in the liminoid stage of the tourism experience. When on holiday tourists may find themselves in a special temporal and spatial dimension, a 'time out of time', or 'place out of place' (Falassi, 1987) that is subject to social rule structures different from everyday situations (Cohen, 1988). Those tourists with a lack of personal resources may in liminoid environments provide help and information to less experienced travellers (Prebensen and Foss, 2011), or conform to the temporary communitas at festivals (Begg, 2011; Morgan, 2007). 
The role of tourism organisations is limited to indentifying, understanding and learning from tourists' $\mathrm{C} 2 \mathrm{C}$ co-creation practices, so that those that appear valuable can be supported and facilitated (Grönroos and Voima, 2011; Korkman, 2006). This is indicated in the mid-section of the framework; the upward- and down-ward facing arrows illustrate the iterative nature of marketers' understanding and facilitating/ supporting tourists' $\mathrm{C} 2 \mathrm{C}$ co-creation. Examples of specific strategies that could be adopted to facilitate $\mathrm{C} 2 \mathrm{C}$ co-creation practices include the following: Tourism marketers can target pre-liminoid practices on the Social Bubble level through marketing communication using for instance various social media platforms (Neuhofer et al., 2012). At festivals, symbolism and artefacts such as bright and colourful gateways could help to mark clearly the point of transformation and entry into the liminoid stage (Getz, 2007), and so help facilitate C2C co-creation on the Communitas level.

Moreover, programming elements and service features delivered in the liminoid stage can also be designed to support specific $\mathrm{C} 2 \mathrm{C}$ co-creation practices. For example, tour guides can try to foster interactions among tourists-strangers through various group activities (Arnould and Price, 1993). At folk music festivals, 'jamming' sessions or various workshops are organised to facilitate the sharing and performing of singing practices among groups of friends but also to facilitate the sense of belonging to temporary communitas (Begg, 2011). Social bonds that form in the liminoid space may result in the emergence of on-going festival careers (Getz, 2007). Tourism marketers could facilitate post-liminoid practices by helping to create social communities centred on specific tourism experiences, again using technology to give tourists an opportunity to engage with each other and nurture relationships on-line (Neuhofer et al., 2012).

\section{Conclusion}

Tourism marketing literature is currently dominated by a position that advocates design and delivery of valuable tourism services and experiences that aim to realise benefits for tourists. In contrast, S-D logic in marketing shifts our attention away from creating value for tourists, toward co-creating value with tourists. S-D logic's value-inperspective then promotes co-created value as dynamic, contextual, and subjectively 
perceived. Yet, the stance proposed in this paper implies that S-D logic does not go far enough in addressing co-creation as a set of tourists' ongoing value-creating social practices in which the organisation's role may be only marginal. Viewing tourists as active co-creators of service experiences who engage in work-like value-creating activities is viewed as a step back toward a reductionist concern for the specific resources - inputs - that tourists need in order to create positive value - outputs - for themselves and for others.

Moreover, this conceptual paper does not subscribe to the view of value in a phenomenological sense as something that is perceived by tourists in the course of their social experiences. As the discussion is centred on $\mathrm{C} 2 \mathrm{C}$ co-creation in social tourism contexts, subjective value is replaced by its shared and mutual forms. Following the logic contained in the recent C-D logic in marketing, this paper views value-in-socialpractice as dynamic, multi-levelled, inter-subjective and embedded in tourists' social practices. As social practices de-centre value from the individual and position it into the practice per se, tourism marketing researchers need to explore in depth the specific contexts in which practices are performed. The notion of the shared 'liminoid' images and social structures present in many tourism and event settings for instance therefore becomes fundamental for a full understanding of $\mathrm{C} 2 \mathrm{C}$ co-creation, as it reflects the shared, socially constructed nature of reality in which tourists' practices are embedded.

With regards to the methodologies needed to undertake $\mathrm{C} 2 \mathrm{C}$ co-creation research as per the practice-based approach, qualitative methodologies grounded in an interpretivist (as opposed to positivist) paradigm are necessary to understand these issues in more depth. As highlighted above, researchers need to recognise the unique social structures and shared images of the tourism social systems in which $\mathrm{C} 2 \mathrm{C}$ cocreation takes place. A social constructionist epistemology is therefore a useful starting point. Research methods such as participant observation grounded in the ethnographic tradition allow for evidence to be gathered of tourists' participation in social practices on the various social levels. By observing naturally-occurring actions and behaviours that constitute a specific practice, and by asking questions about the personal and contextual aspects of that practice, researchers can to link the action and meaning of the action into a credible account of tourists' co-creation. 
The conceptual framework builds on literature specific to the somewhat unique nature of liminoid tourism settings in which a sense of togetherness and 'communitas' (Turner, 1982) may emerge. Nevertheless, future research could apply the notion of social practices as a source of value co-creation in other $\mathrm{C} 2 \mathrm{C}$ interaction-rich contexts, provided that the situational and contextual elements of social practices are fully acknowledged. Researchers could, for instance, illuminate the nature and appeal of shared consumption of various tourist groups or subcultures that emerge in specific tourism situations, such as strangers co-participating in guided tours, clubbers in island destinations, or families visiting heritage tourism attractions. Similarly, the proposed framework may be of interest to researchers looking at co-creation in the context of festivals, conferences and business events. Additionally, future studies could break down the framework and look in detail at the specific elements/components of tourists' social practices in the pre-, during, and post-liminoid stages of tourism experiences. Empirical testing of the framework is also desirable.

The tourism industry is full of experiences of a social nature, in which people with similar interests, motivations and goals meet together and interact. Rather than striving to persuade socialising tourists that the service offering is valuable to them in some way, tourism organisations benefit from recognising how they can potentially play a role in facilitating tourists' ongoing $\mathrm{C} 2 \mathrm{C}$ co-creation processes. The theoretical discussion in this paper highlights different perspectives that exist in more holistic value paradigms. The conceptual framework then presents a novel approach to value cocreation research in tourism marketing. By drawing on empirical studies built on frameworks such as this, tourism organisations can design their value propositions based on more in-depth and all encompassing knowledge of what tourists actually do with their service. 


\section{References}

Arnould, E. J., Price, L. L. 1993. River magic: extraordinary experience and the extended service encounter. The Journal of Consumer Research 20(1): 24-45.

Baker, D. A., Crompton, J. L. 2000. Quality, satisfaction and behavioral intentions. Annals of Tourism Research 27(3): 785-804.

Baron, S., Harris, K. 2010. Toward an understanding of consumer perspectives on experiences. Journal of Services Marketing 24(7): 518-531.

Begg, R. 2011. Culturing commitment: serious leisure and the folk festival experience in Gibson, C. and Connell, J. (eds.). Festival places: revitalising rural Australia. Channel View Publications: Bristol: 248-264.

Bendapudi, N., Leone, R. P. 2003. Psychological implications of customer participation in coproduction. Journal of Marketing 67(1): 14-28.

Berger, P. L., Luckmann, T. 1967. The social construction of reality: a treatise in the sociology of knowledge. Penguin: London.

Binkhorst, E., Den Dekker, T. 2009. Agenda for co-creation tourism experience research. Journal of Hospitality Marketing \& Management 18(2): 311-327.

Brown, B., Chalmers, M., MacColl, I. Brown, B., Chalmers, M., MacColl, I. Exploring tourism as a collaborative activity. Technical Report Equator 02-018. University of Glasgow, Department of Computer Science: Glasgow

Cabiddu, F., Lui, T.-W., Piccoli, G. 2013. Managing value co-creation in the tourism industry. Annals of Tourism Research 42(0): 86-107.

Clarke, J. 2013. Experiential aspects of tourism gift consumption. Journal of Vacation Marketing 19(1): 75-87.

Cohen, E. 1988. Traditions in the qualitative sociology of tourism. Annals of Tourism Research 15(1): 29-46.

Cole, S. T., Chancellor, C. 2009. Examining the festival attributes that impact visitor experience, satisfaction and re-visit intention. Journal of Vacation Marketing 15(4): 323-333.

Cova, B. 1997. Community and consumption: towards a definition of the "linking value" of product or services. European Journal of Marketing 31(3/4): 297-316.

Cova, B., Dalli, D. 2009. Working consumers: the next step in marketing theory? Marketing Theory 9(3): 315-339.

Csikszentmihalyi, M. 1997. Finding flow: the psychology of engagement with everyday life. BasicBooks: New York.

Edvardsson, B., Tronvoll, B., Gruber, T. 2011. Expanding understanding of service exchange and value co-creation: a social construction approach. Journal of the Academy of Marketing Science 39(2): 327-339.

Falassi, A. 1987. Time out of time: essays on the festival. University of New Mexico Press: Albuquerque, NM.

Finsterwalder, J., Tuzovic, S. 2010. Quality in group service encounters: a theoretical exploration of the concept of a simultaneous multi-customer co-creation process. Managing Service Quality 20(2): 109-122.

Gainer, B. 1995. Ritual and relationships: interpersonal influences on shared consumption. Journal of Business Research 32(3): 253-260.

Getz, D. 2007. Event studies: theory, research and policy for planned events. ButterworthHeinemann: Oxford.

Goulding, C., Shankar, A. 2011. Club culture, neotribalism and ritualised behaviour. Annals of Tourism Research 38(4): 1435-1453. 
Griessmann, U. S., Stokburger-Sauer, N. E. 2012. Customer co-creation of travel services: the role of company support and customer satisfaction with the co-creation performance. Tourism Management 33(6): 1483-1492.

Grönroos, C. 2008. Service logic revisited: who creates value? And who co-creates? European Business Review 20(4): 298-314.

Grönroos, C. 2011. Value co-creation in service logic: a critical analysis. Marketing Theory 10(3): 279-301.

Grönroos, C., Voima, P. 2011. Making sense of value and value co-creation in service logic. Working Paper No. 559 [Online], available from: https://helda.helsinki.fi/ handle/10138/29218 (Accessed March 23, 2012).

Heinonen, K., Strandvik, T., Mickelsson, K. J., Edvardsson, B., Sundström, E., Andersson, P. 2010. A customer-dominant logic of service. Journal of Service Management 21(4): 531-548.

Helkkula, A., Kelleher, C. 2011. Experiences and practices: challenges and opportunities for value researc. Paper presented at the 2011 Naples Forum on Service - Service Dominant logic, network \& system theory and service science: integrating three perspectives for a new service agenda, 14th - 17th June, Capri, Italy.

Helkkula, A., Kelleher, C., Pihlström, M. 2012. Characterizing value as an experience: implications for service researchers and managers. Journal of Service Research 15(1): 59-75.

Holbrook, M. B. 1999. Introduction in Holbrook, M. B. (ed.) Consumer value: a framework for analysis and research. Routledge: London: 1-28.

Holt, D. B. 1995. How consumers consume: a typology of consumption practices. Journal of Consumer Research 22(1): 1-16.

Holttinen, H. 2010. Social practices as units of value creation: theoretical underpinnings and implications. International Journal of Quality and Service Sciences 2(1): 95-112.

Huang, J., Hsu, C. H. C. 2010. The impact of customer-to-customer interaction on cruise experience and vacation satisfaction. Journal of Travel Research 49(1): 79-92.

Husserl, E. [1936] 1970. The Crisis of European Sciences and Transcendental Phenomenology [trans. David Carr]. Northwestern University Press: Evanston, IL.

Kim, H., Jamal, T. 2007. Touristic quest for existential authenticity. Annals of Tourism Research 34(1): 181-201.

Korkman, O. 2006. Customer value formation in practice: a practice-theoretical approach. Doctoral thesis. Hanken Swedish School of Economics, Finland.

Kotler, P., Keller, K. L., Brady, M. K., Goodman, M., Hansen, T. 2009. Marketing management. Pearson Education: Harlow.

Lehto, X. Y., Choi, S., Lin, Y.-C., MacDermid, S. M. 2009. Vacation and family functioning. Annals of Tourism Research 36(3): 459-479.

Levy, S. E., Getz, D. 2012. An exploration of social stimuli influencing the student sightseeing tour experience. Tourism Review International 15(4): 297-311.

Li, X. R., Petrick, J. F. 2008. Tourism marketing in an era of paradigm shift. Journal of Travel Research 46(3): 235-244.

Löbler, H. 2011. Position and potential of service-dominant logic: evaluated in an 'ism' frame for further development. Marketing Theory 11(1): 51-73.

MacCannell, D. 1976. The tourist: a new theory of leisure class. Schocken Books: New York, NJ.

Mackellar, J. 2009. An examination of serious participants at the Australian Wintersun Festival. Leisure Studies 28(1): 85-104.

McColl-Kennedy, J. R., Tombs, A. 2011. When customer value co-creation diminishes value for other customers deliberately or inadvertently. Paper presented at the 2011 Naples 
Forum on Service - Service Dominant logic, network \& system theory and service science: integrating three perspectives for a new service agenda, 14th - 17th June, Capri, Italy.

Morgan, M. 2007. 'We're not the Barmy Army!': reflections on the sports tourist experience. International Journal of Tourism Research 9(5): 361-372.

Neuhofer, B., Buhalis, D., Ladkin, A. 2012. Conceptualising technology enhanced destination experiences. Journal of Destination Marketing \& Management 1(1/2): 36-46.

Oh, H., Fiore, A. M., Jeoung, M. 2007. Measuring experience economy concepts: tourism applications. Journal of Travel Research 46(2): 119-132.

Packer, J., Ballantyne, J. 2011. The impact of music festival attendance on young people's psychological and social well-being. Psychology of Music 39(2): 164-181.

Payne, A. F., Storbacka, K., Frow, P. 2008. Managing the co-creation of value. Journal of the Academy of Marketing Science 36(1): 83-96.

Pegg, S., Patterson, I. 2010. Rethinking music festivals as a staged event: gaining insights from understanding visitor motivations and the experiences they seek. Journal of Convention and Event Tourism 11(2): 85-99.

Pine, B. J., Gilmore, J. H. 1999. The experience economy: work is theatre and every business a stage. Harvard Business School Press: Boston, MA.

Prebensen, N. K., Foss, L. 2011. Coping and co-creating in tourist experiences. International Journal of Tourism Research 13(1): 54-67.

Prebensen, N. K., Vitters $\varnothing$, J., Dahl, T. I. 2013. Value co-creation significance of tourist resources. Annals of Tourism Research 42(0): 240-261.

Rantala, O. 2010. Tourist practices in the forest. Annals of Tourism Research 37(1): 249-264.

Rihova, I., Buhalis, D., Moital, M., Gouthro, M. B. 2013. Social layers of customer-tocustomer value co-creation. Journal of Service Management 24(5): 553 - 566.

Ryan, C. 2002. The tourist experience. 2nd ed. Continuum: London.

Schatzki, T. R. 1996. Social practices: a Wittgensteinian approach to human activity and the social. Cambridge University Press: Cambridge.

Schatzki, T. R. 2001. Introduction: practice theory in Schatzki, T. R., et al. (eds.). The practice turn in contemporary theory. Routledge: New York, NJ: 10-23.

Selby, M. 2004. Consuming the city: conceptualizing and researching urban tourist knowledge. Tourism Management 6(2): 186-207.

Sfandla, C., Björk, P. 2013. Tourism experience network: co-creation of experiences in interactive processes. International Journal of Tourism Research 15(5): 495-506.

Shaw, G., Bailey, A., Williams, A. 2011. Aspects of service-dominant logic and its implications for tourism management: examples from the hotel industry. Tourism Management 32(2): 207-214.

Thrane, C. 2002. Music quality, satisfaction, and behavioral intentions within a jazz festival context. Event Management 7(3): 143-150.

Tronvoll, B., Brown, S. W., Gremler, D. D., Edvardsson, B. 2011. Paradigms in service research. Journal of Service Management 22(5): 560 - 585.

Turnbull, J. 2009. Customer value-in-experience: theoretical foundation and research agenda. Paper presented at the Australian and New Zealand Marketing Academy Conference (ANZMAC): Sustainable management and marketing. 30th November 2nd December, Melbourne, Australia.

Turner, V. W. 1995. The ritual process: structure and anti-structure (with a foreword by Roger D. Abrahams). Aldine de Gruyter: New York, NJ.

Uriely, N. 2005. The tourist experience: conceptual developments. Annals of Tourism Research 32(1): 199-216. 
Van Limburg, B. 2009. Innovation in pop festivals by cocreation. Event Management 12(2): 105-117.

Vargo, S. L. 2011. On marketing theory and service-dominant logic: connecting some dots. Marketing Theory 11(1): 3-8.

Vargo, S. L., Lusch, R. L. 2004. Evolving to a new dominant logic for marketing. Journal of Marketing 68(1): 1-17.

Vargo, S. L., Lusch, R. L. 2008. Service-dominant logic: continuing the evolution. Journal of the Academy of Marketing Science 36(1): 1-10.

Voima, P., Heinonen, K., Strandvik, T. 2010. Exploring customer value formation: a customer dominant logic perspective. Working Paper No. 552 [Online], available from: https://helda.helsinki.fi/handle/10227/630 (accessed November 26, 2011).

Walker, C. J. 2010. Experiencing flow: is doing it together better than doing it alone? The Journal of Positive Psychology 5(1): 3 - 11.

Walls, A. R. 2013. A cross-sectional examination of hotel consumer experience and relative effects on consumer values. International Journal of Hospitality Management 32(1): 179-192.

Warde, A. 2005. Consumption and theories of practice. Journal of Consumer Culture 5(2): 131-153.

Wilks, L. 2011. Bridging and bonding: social capital at music festivals. Journal of Policy Research in Tourism, Leisure and Events 3(3): 281-297.

Woodall, T. 2003. Conceptualising value for the customer: an attributional, structural and dispositional analysis. Academy of Marketing Science Review 12(1-42.

Zeithaml, V. A., Berry, L. L., Parasuraman, A. 1988. Communication and control processes in the delivery of service quality. The Journal of Marketing 52(2): 35-48. 
Figure 1: $\mathrm{C} 2 \mathrm{C}$ co-creation in tourism

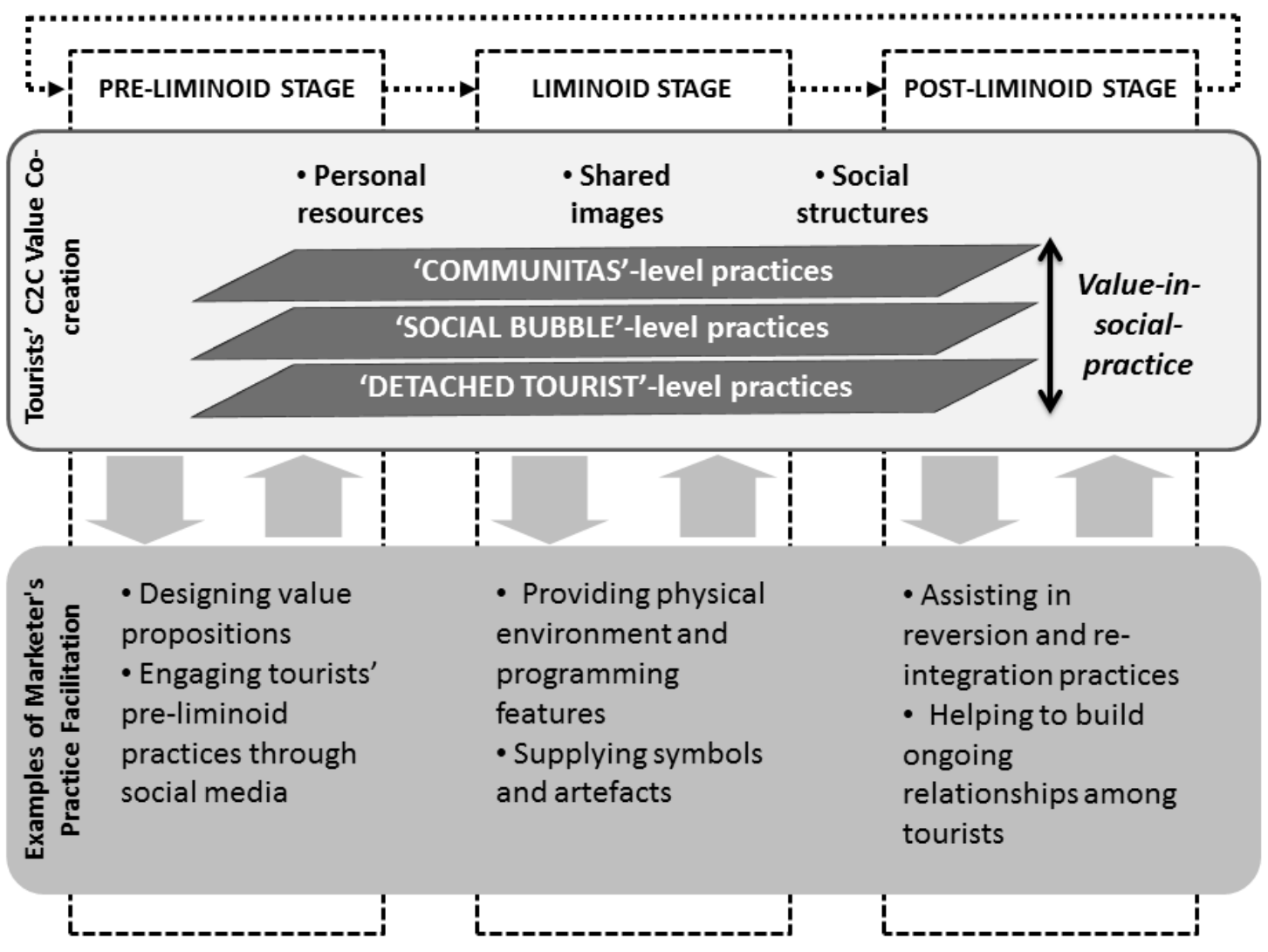

